\title{
Partial Shade, Irrigation, and Added Nutrients Maximize Dry Matter Yield of American Skullcap (Scutellaria lateriflora L.)
}

\author{
Arsène Similien \\ Agricultural Division, SEED Ministries Inc., P.O. Box 32, Warf-Massé, \\ Les Cayes, Haiti, West Indies
}

Dennis A. Shannon ${ }^{1}$, C. Wesley Wood, and Edzard van Santen
Department of Agronomy and Soils, 202 Funchess Hall, Auburn University,
AL 36849

Nirmal Joshee

Agricultural Research Station, Fort Valley State University, GA 31030

Wheeler G. Foshee
Department of Horticulture, Auburn University, AL 36849

Additional index words. manure, fertilizer, medicinal plants

\begin{abstract}
American skullcap (Scutellaria lateriflora L.), a medicinal plant species valued for its sedative properties associated with flavonoids, is generally harvested from the wild. Scientific information on how field cultivation practices affect dry matter yield is lacking in this species. A $2 \times 2 \times 3$ split plot factorial experiment within a randomized complete block design was conducted on a Marvyn loamy sand (fine-loamy, kaolinitic, Thermic Typic Kanhapludults) in Central Alabama to explore effects of light, irrigation, and nutrient application on dry matter yield of American skullcap. Treatment factors were shade ( $40 \%$ shade vs. no shade), irrigation (applied at $30 \mathrm{kPa} v$ s. no irrigation), and nutrients [no added nutrients vs. nutrients added as chemical fertilizer (100 kg nitrogen, $68 \mathrm{~kg}$ phosphorus, $42 \mathrm{~kg}$ potassium/ha) or chicken litter (100 kg nitrogen, $50 \mathrm{~kg}$ phosphorus, and $123 \mathrm{~kg}$ potassium/ha)]. Shade formed the main plot units, whereas irrigation $\times$ nutrient factorial combinations were subplots. Skullcap shoots in experimental plots were harvested four times during the course of the two-year experiment (2007, 2008). All growth variables measured, except percent dry matter, performed better under shade than in full sun. Dry matter yield was increased $45 \%$ by shade, $61 \%$ by irrigation, and $22 \%$ by addition of nutrients. A significant irrigation $\times$ nutrients interaction was observed at the first and second harvests. Highest yields were obtained with the irrigation + manure and irrigation + fertilizer treatments under shade and the lowest with fertilizer and the control treatments in full sun.
\end{abstract}

Before the advent of synthetic medicines, plants were a main source of medicine (Mannfried, 1993). A resurgence in the use of herbal medicine (Azaizeh et al., 2005) creates a need to cultivate medicinal plants traditionally harvested in the wild. Benefits of cultivation of medicinal plants include uniformity of herbal material and prevention of incorrect identification, adulteration, and loss of the wild gene pool (Azaizeh et al., 2005; Sturdivant and Blakley, 1999).

American skullcap (Scutellaria lateriflora L.) was traditionally used by Native Americans to treat many illnesses (Wills and Stuart, 2004). Currently, the herb is mainly used for

Received for publication 18 July 2011. Accepted for publication 12 Oct. 2012.

We thank the Alabama Agricultural Land Grant Alliance for partial support for this research.

${ }^{1}$ To whom reprint requests should be addressed; e-mailshannda@auburn.edu. its sedative properties (Upton, 2009) and is in high demand in the herbal products industry (Brevoort, 1998). American skullcap is naturally found in moist and wooded areas (Awad et al., 2003; Foster and Duke, 2000) and is classified as a facultative wetland plant (USDA, 2011). The plant has been grown successfully in full sun and partial shade (Janke and DeArmond, 2004; Joshee et al., 2002). Most research on American skullcap has focused on identifying and extracting chemical constituents present in the plant tissues (e.g., Awad et al., 2003; Bergeron et al., 2005). Field experiments on Scutellaria baicalensis were reported by Zheljazkov et al. (2007); however, there is no report of agronomic experiments conducted on American skullcap under field conditions in the United States. The two species differ considerably in adaptation, and S. lateriflora is cultivated for aboveground leaves and stem, whereas roots are harvested in case of S. baicalensis.
The objectives of this research were to 1) evaluate the potential for American skullcap to be successfully grown under regular farming practices; and 2) determine growing conditions needed to optimize total dry matter yield. Factors tested were light, water, and nutrients. The effect of the growing conditions tested on flavonoid content in skullcap will be reported separately.

\section{Materials and Methods}

Site description and land preparation. The experiment was conducted at the Horticulture Unit of the E.V. Smith Research Center, near Shorter, AL, on a Marvyn loamy sand (fine-loamy, kaolinitic, Thermic Typic Kanhapludults), $2 \%$ to $5 \%$ slope. Soil $\mathrm{pH}$ measured in Dec. 2006 before liming and on 22 Mar. $200710 \mathrm{~d}$ after liming were, respectively, 5.1 and 5.8 with a cation exchange capacity of $4.6 \mathrm{cmol}_{\mathrm{c}} \cdot \mathrm{kg}^{-1}$.

Before tillage, weeds were controlled using $2.1 \mathrm{~kg}$ glyphosate herbicide (Roundup) a.i./ha. A preliminary tillage operation was done in Mar. 2007 using a disk harrow. After the first tillage and after liming, five soil samples were taken from each experimental block at a depth of 0 to $15 \mathrm{~cm}$ to determine $\mathrm{pH}$ and primary nutrients [nitrogen $(\mathrm{N})$, phosphorus $(\mathrm{P})$, and potassium $(\mathrm{K})$ ] content. A second tillage operation was done on $9 \mathrm{Apr}$. 2007 using a RHINO SHV80 rototiller to loosen the soil. Dolomitic limestone was applied at the rate of $2500 \mathrm{~kg} \cdot \mathrm{ha}^{-1}$ in Mar. 2007 before the second tillage and before bedding. Chemical fertilizer and chicken litter were hand-broadcasted on respective plots on 6 Apr. 2007 before bedding. An 18-inch wide bedder (Reddick Fumigants, LLC, Williamston, NC) was used to prepare beds and place drip irrigation lines simultaneously on 10 Apr. 2007. Beds were covered with weed guard groundcover manufactured from ultraviolet-resistant black polyethylene to help control weeds while allowing air and water to reach the plant root system. Holes $\approx 5 \mathrm{~cm}$ in diameter were cut at a spacing of $30 \mathrm{~cm} \times 30 \mathrm{~cm}$ to allow for transplanted seedlings. Pine bark mulch was spread over the fabric to help control weeds between and on beds. On 7 Apr. 2008, immediately after emergence of new foliage in Year 2, the mulch fabric was removed from all plots to allow stolons, which had spread under the fabric, to grow shoots.

Experimental design and treatments. The experiment was a $2 \times 2 \times 3$ split plot factorial in a randomized complete block design $(r=4)$. The shade factor formed the main plot units, whereas irrigation and nutrients were subplots. Subplots measured $1.2 \times$ $6.1 \mathrm{~m}\left(7.43 \mathrm{~m}^{2}\right)$ and each subplot consisted of 40 plants. Seedlings were spaced $30 \times 30 \mathrm{~cm}$, yielding a population density of 53,800 plants/ ha assuming a full stand. Single drip lines $16 \mathrm{~mm}$ inner diameter, $250-\mathrm{mm}$ wall, $30-\mathrm{cm}$ spacing between drippers, $340 \mathrm{~L} / \mathrm{H}$ flow/ $100 \mathrm{~m}$ at 0.55 bars pressure were installed down the center of each bed. The two irrigation levels were none and irrigation 
applied when soil moisture tension reached $-30 \mathrm{kPa}$.

The nutrient factors were an untreated control, chemical fertilizer $(100 \mathrm{~kg} \mathrm{~N}, 68 \mathrm{~kg}$ $\mathrm{P}, 42 \mathrm{~kg} \mathrm{~K} / \mathrm{ha})$, and chicken litter (100 kg N, $50 \mathrm{~kg} \mathrm{P}, 123 \mathrm{~kg} \mathrm{~K} / \mathrm{ha}$ ). In Year 2, chemical fertilizer (136 kg N/ha, $125 \mathrm{~kg} \mathrm{P} / \mathrm{ha}, 110 \mathrm{~kg}$ $\mathrm{K} / \mathrm{ha}$ ), and chicken litter (136 kg N/ha, $68 \mathrm{~kg}$ $\mathrm{P} / \mathrm{ha}, 102 \mathrm{~kg} \mathrm{~K} / \mathrm{ha}$ ) were reapplied based on soil test results. Composted poultry litter organic pelletized fertilizer $(4 \mathrm{~N}-2 \mathrm{P}-3 \mathrm{~K})$ from Longwood Plantation, Newington, GA, was used instead of the dried poultry litter used in Year 1. The pelletized poultry litter also provided $102 \mathrm{~kg}$ calcium/ha, $17 \mathrm{~kg}$ magnesium $/ \mathrm{ha}, 4.42 \mathrm{~kg}$ iron/ha, and 2.38 $\mathrm{kg} \cdot \mathrm{ha}^{-1}$ of copper, manganese, and zinc.

Sun Blocker Commercial Shade Houses (FarmTek, Dyersville, IA) measuring $7.3 \mathrm{~m}$ wide $-9.1 \mathrm{~m}$ long were assembled on site. Shade covers manufactured from knitted polyethylene fabric to provide $40 \%$ shade were placed on top of a steel frame and around the south, west, and east sides of the frame. Shade houses were oriented northsouth, whereas plots were oriented east-west.

Seedling establishment and husbandry. Seed of S. lateriflora (Horizon Herbs LLC, William, OR) were cold-stratified in moist potting mix at $4{ }^{\circ} \mathrm{C}$ in the dark for $8 \mathrm{~d}$ ( 15 to 23 Feb. 2007). The potting mix, Sunshine Professional Peat-Lite Mixes \# 8/LC 8 by Sun Gro Horticulture Canada Ltd., Vancouver, British Columbia, was used both in flats and multicell trays. The mix was formulated with Canadian sphagnum peatmoss, coarsegrade perlite, coarse-grade vermiculite, dolomitic limestone, gypsum, and long-lasting wetting agent. The flats were transferred to a growth chamber on 23 Feb. 2007, where they were supplied with mist irrigation (Flora-Mist) for $1 \mathrm{~min}$ every hour from $0600 \mathrm{HR}$ to $1600 \mathrm{HR}$. Four $400-\mathrm{W}$ sodium lamps provided a photoperiod of $12 \mathrm{~h}$. The temperature was maintained at $\approx 25.5^{\circ} \mathrm{C}$.

When seedlings reached $5 \mathrm{~cm}$ height, they were transferred to the greenhouse on 7 Mar. Individual seedlings were transplanted to 72cell trays between 9 and 13 Mar. After transplantation, day and night temperatures were kept at 24.4 and $21.1^{\circ} \mathrm{C}$, respectively. Seedlings were sprinkle irrigated daily. Peter's 20-10-20 Peat-Lite Special water-soluble fertilizer (Scotts Company, Marysville, $\mathrm{OH}$ ) was applied twice after transplantation at the rate of $250 \mathrm{mg} \cdot \mathrm{L}^{-1}$. Seven $\mathrm{d}$ before transplanting, seedlings were placed in full sun to harden. They were transplanted to the field during the last week of Apr. 2007. At transplanting, seedlings averaged $12 \mathrm{~cm}$ tall with 10 true leaves based on a random sample of five plants per tray. Soil moisture at this location was low and the most recent precipitation of $18.8 \mathrm{~mm}$ rainfall was recorded $10 \mathrm{~d}$ before transplanting. Soil temperature at $10 \mathrm{~cm}$ and air temperature were, respectively, 19.7 and $16.6{ }^{\circ} \mathrm{C}$ (Alabama Mesonet).

Drip irrigation was applied to all treatments until complete establishment of the plants. Dead seedlings were replaced periodically until full stands were obtained. Twenty days after transplanting, on 20 May 2007, driplines were cut from non-irrigated treatments. Four tensiometers, (Irrometer Co., Riverside, CA) were placed at $15-\mathrm{cm}$ depth in fertilized irrigated and fertilized non-irrigated plots under shade and in full sun in Blocks 1 and 3. Tensiometer readings were taken only in irrigated plots in 2008. Soil moisture tension was recorded twice weekly and irrigation was provided to all irrigated plots when soil moisture tension reached $30 \mathrm{kPa}$ in the irrigated treatments. In 2007, $348 \mathrm{~mm}$ of rainfall was recorded between planting and second harvest and an estimated $267 \mathrm{~mm}$ irrigation water was applied to irrigated plots. In 2009, $322 \mathrm{~mm}$ rainfall was recorded between emergence and second harvest, whereas an estimated $191 \mathrm{~mm}$ water was applied in irrigated plots. Irrigation treatments received $\approx 76 \%$ and $59 \%$ more water than non-irrigated treatments in 2007 and 2008, respectively.

Weeds on top and between beds were hand-pulled. The herbicide, sethoxydim (Poast), was applied twice during the growing period between and around the beds at $0.54 \mathrm{~kg}$ a.i./ha to control annual grasses. Powdery mildew, found mainly under shade, was the main problem encountered during production; only a few plants were affected in full sun. The pathogen was controlled with weekly applications of a mixture of Sunspray Ultra horticultural fine oil (Farnam Companies, Inc., Phoenix, AZ) at $3.1 \mathrm{~mL} \cdot \mathrm{L}^{-1}$ and potassium bicarbonate (Millstop $85 \%$ potassium bicarbonate) at the rate of $3.97 \mathrm{mg} \cdot \mathrm{L}^{-1}$. Spraying was done 1 June, 7 June, 14 June, and 19 June 2007. Neem oil extract (Trilogy;

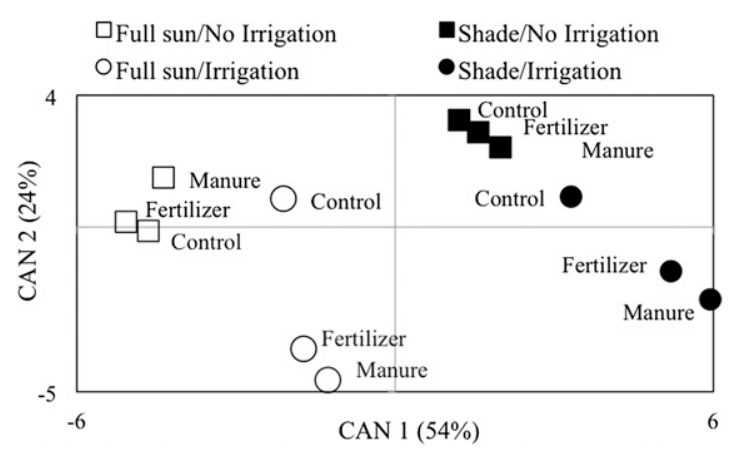

Fig. 1. Centroid means from canonical discriminant analysis of plant density, plant height, dry matter percentage, and dry matter yield using treatments as classification variable.

Table 1. Significance levels for main effects and interactions for plant density, plant height, dry matter content, and dry matter yield of American skullcap in 2007 and $2008 .^{z}$

\begin{tabular}{|c|c|c|c|c|}
\hline \multirow[b]{2}{*}{ Response variable/source of variation } & \multicolumn{2}{|c|}{2007} & \multicolumn{2}{|c|}{2008} \\
\hline & Harvest 1 & Harvest 2 & Harvest 3 & Harvest 4 \\
\hline \multicolumn{5}{|l|}{ Plant density } \\
\hline Shade & 0.808 & 0.062 & 0.006 & $<0.001$ \\
\hline Irrigation & 0.917 & 0.023 & $<0.001$ & 0.004 \\
\hline Shade*irrigation & 0.688 & 0.156 & 0.347 & 0.624 \\
\hline Nutrient & 0.534 & 0.009 & 0.002 & 0.183 \\
\hline Shade*nutrient & 0.878 & 0.018 & 0.783 & 0.659 \\
\hline Irrigation*nutrient & 0.257 & 0.231 & 0.002 & 0.121 \\
\hline \multicolumn{5}{|l|}{ Plant height } \\
\hline Shade & $0.003^{y}$ & $<0.001$ & $<0.001$ & 0.002 \\
\hline Irrigation & $<0.001$ & 0.001 & $<0.001$ & 0.002 \\
\hline Shade*irrigation & 0.633 & 0.703 & 0.463 & 0.039 \\
\hline Nutrient & 0.016 & 0.803 & $<0.001$ & 0.123 \\
\hline Shade*nutrient & 0.044 & 0.076 & 0.029 & $<0.001$ \\
\hline Irrigation*nutrient & 0.820 & 0.019 & 0.001 & 0.204 \\
\hline \multicolumn{5}{|l|}{ Dry matter content } \\
\hline Shade & 0.004 & 0.007 & 0.002 & $<0.001$ \\
\hline Irrigation & $<0.001$ & 0.001 & $<0.001$ & 0.299 \\
\hline Shade*irrigation & 0.790 & 0.007 & 0.022 & 0.736 \\
\hline Nutrient & 0.837 & 0.001 & 0.013 & $<0.001$ \\
\hline Shade*nutrient & 0.486 & 0.880 & 0.867 & 0.148 \\
\hline Irrigation*nutrient & 0.705 & 0.075 & 0.313 & 0.249 \\
\hline \multicolumn{5}{|l|}{ Dry matter yield } \\
\hline Shade & 0.153 & 0.014 & 0.096 & 0.005 \\
\hline Irrigation & 0.002 & 0.681 & $<0.001$ & 0.087 \\
\hline Shade*irrigation & 0.610 & 0.152 & 0.553 & 0.517 \\
\hline Nutrient & $<0.001$ & 0.761 & $<0.001$ & 0.991 \\
\hline Shade*nutrient & 0.159 & 0.465 & 0.180 & 0.269 \\
\hline Irrigation*nutrient & 0.432 & 0.001 & 0.001 & 0.181 \\
\hline
\end{tabular}

zThe three-way interaction was eliminated from the model because of $P>0.10$.

${ }^{y}$ Bold numbers indicate $P \leq 0.10$. 
Certis USA, LLC, Columbia, MD) was applied for powdery mildew control at the rate of $1.25 \%$ to $1.5 \%$ solutions (12.5 to $15 \mathrm{~mL} \cdot \mathrm{L}^{-1}$ ) on 20 Aug. 2007 and four times in 2008 (18 May, 27 May, 10 June, and 25 July).

Plant density, plant height, dry matter percentage, and dry matter yield determinations. Four harvests, designated $\mathrm{H} 1, \mathrm{H} 2, \mathrm{H} 3$, and $\mathrm{H} 4$, were carried out at full bloom on 29 June and 5 Sept. in 2007 and on 13 June and 25 July in 2008. This represents growth intervals of 9 to 10 weeks after transplanting, pruning, or emergence after winter, except for the final harvest, which occurred 6 weeks after the previous harvest. Plant height, based on average of five samples taken at random from each plot, was taken $1 \mathrm{~d}$ before each harvest. The aboveground portion of each plant was cut $7.5 \mathrm{~cm}$ from the ground using pruning shears in 2007 and a gasoline-driven hand trimmer in 2008. The central 32 plants $\left(5.7 \mathrm{~m}^{2}\right)$ of each plot were harvested and weighed to determine total fresh yield. A 250-g sample was taken from each plot to determine percent dry matter and calculate dry matter yield. Samples were placed in $30 \times 60$-cm paper bags perforated at the bottom and on the side to allow air circulation. In 2007, bags containing samples were placed with open tops in a forcedair dryer (Model AA-5460A; Parameter Generation and Control Inc., Black Mountain, NC) at $40{ }^{\circ} \mathrm{C}$ for $3 \mathrm{~d}$. In 2008 , drying was done using a forage dryer at $43{ }^{\circ} \mathrm{C}$ for $3 \mathrm{~d}$ at Harvest 3 and a drying shed at $38{ }^{\circ} \mathrm{C}$ for $4 \mathrm{~d}$ at Harvest 4 . Once removed from the dryer, samples were weighed to determine percent dry matter. Number of plants harvested for each plot was counted after each harvest to determine plant stand per treatment. Before Harvest 3, the mulch fabric had been removed and shoots covered the beds, making it impossible to count individual plants. Instead of individual plants, number of shoots was counted from two $625-\mathrm{cm}^{2}$ quadrants per plot at Harvests 3 and 4 to determine plant populations.

Data analysis. All data were analyzed using PROC GLIMMIX mixed models procedures as implemented in SAS Version 9.1.3 (SAS Institute, Cary, NC). All treatment factors and their interactions were considered to be fixed effects. Because the design was a randomized complete block with a split plot restriction on randomization the model contained the two random effects block, and shade $\times$ block, where the latter served as the appropriate error term for shade effects. The residual error term was used to test subplot factors, their interactions with each other as well as with the main plot factor shade. Because the three-way interaction was non-significant $(P>0.1)$ in all instances, the final model did not contain this interaction. Dunnett's test was used to compare inorganic and organic fertilizer treatments with the untreated control. Canonical discriminant analysis was performed to help guide the interpretation of pattern observed among the 17 responses variables observed over this two-year experiment.

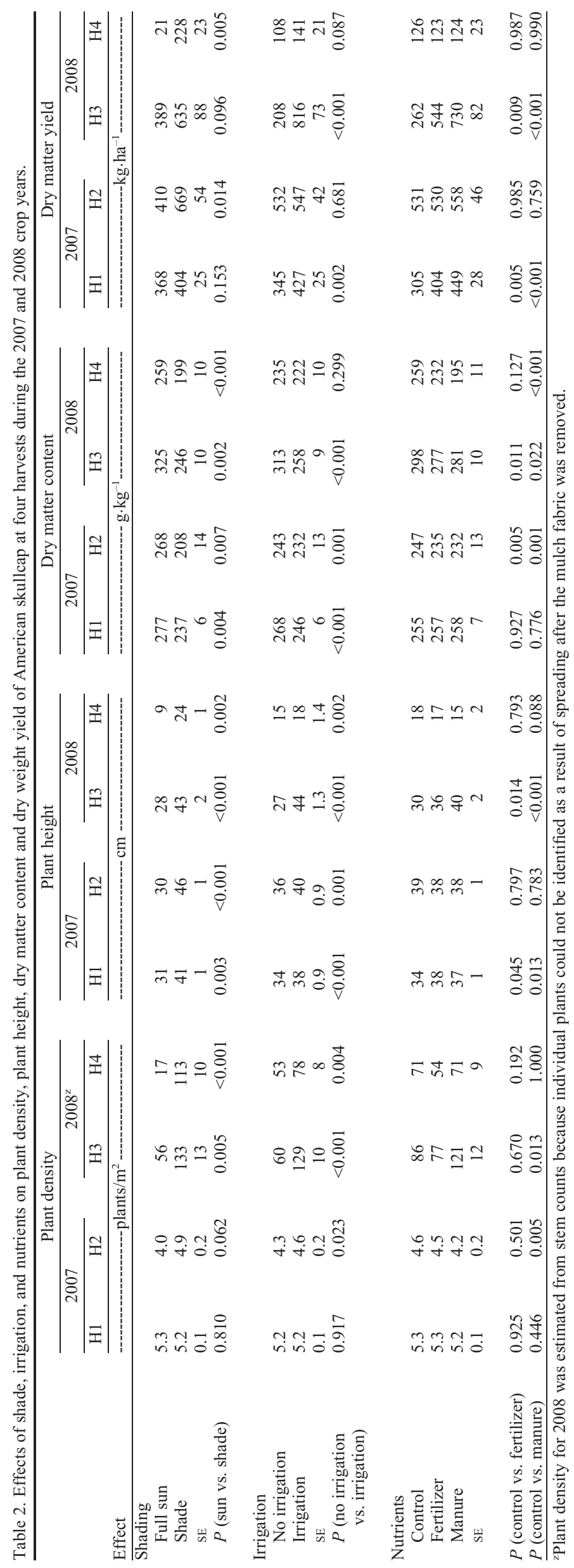

1707 


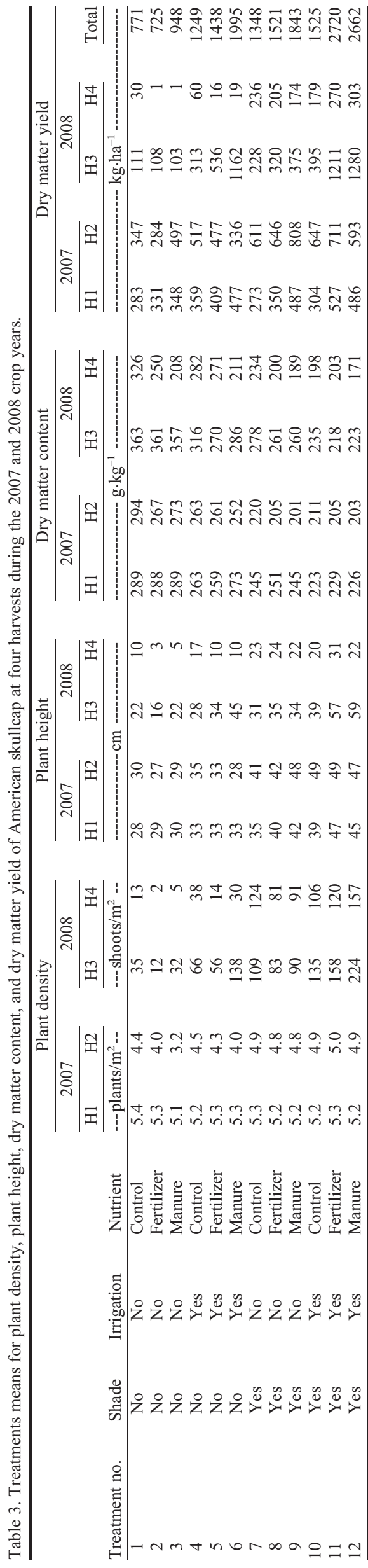

\section{Results and Discussion}

The centroid means (Fig. 1) for the first two canonical variates revealed interesting patterns: 1) the four shade $\times$ irrigation groups clearly separated along CAN 1 in the order full sunlight without irrigation, full sunlight with irrigation, shade without irrigation, and shade with irrigation; 2) treatments without irrigation are tightly grouped; and (3) added nutrients in irrigated treatment groups elicited a strong separation from the zero fertilizer treatment within that group. Differences among CAN 1 were driven by high positive phenotypic correlations ( $r \geq$ 0.92) for plant height in 2007, plant density and dry matter yield at the last harvest as well as high negative correlations $(r \leq-0.92)$ for dry matter content during the first three harvests (data not shown). Differences among CAN 2 were driven by negative phenotypic correlations $(-0.68 \leq r \leq-0.38)$ for dry matter yield at the first three harvests, total dry matter yield, and plant height at Harvest 3 (data not shown).

Canonical analysis revealed that shade and irrigation were controlling factors affecting measured variables (Fig. 1). Fertilizer had an effect, but only when sufficient water was present.

Plant density. Absence of shade or irrigation significantly reduced stands (Tables 1 and 2). With each successive harvest, shade became a greater determinant of plant density because stand losses under full sunlight were quite high; stands under full sunlight declined from $83 \%$ at harvest 2 to $15 \%$ at Harvest 4 compared with the shaded plots. Stands without irrigation declined from $94 \%$ at Harvest 2 to $68 \%$ in Harvest 4 compared with the irrigated control. Conditions were especially dry during June and Aug. 2007 and May through early June 2008, although irrigation was also required during other periods. Poor survival and growth without irrigation and in full sun is consistent with skullcap's classification as a facultative wetland species (USDA, 2011). The nutrient effect was significant in Harvests 2 and 3 but inconsistent among harvests. Significant interactions among factors were present at Harvests 2 and 3 (Table 1) but of lesser importance in explaining the response patterns. They can be deduced from the means presented in Table 3; highest densities generally were achieved when manure was added to irrigated plots irrespective of shading treatment.

Plant height. Shade increased plant height at all harvests (Table 2) by amounts ranging from $32 \%$ at Harvest 1 to 1.7 -fold at Harvest 4. Similarly, irrigation increased plant height $11 \%$ to $63 \%$ averaged over shade or nutrient treatment with the most pronounced effects at Harvest 3 (Table 2). The significant two-way interactions involving shade and irrigation (Table 1) were the result of changes in magnitude of the responses and not rank changes.

The average response to added nutrients was inconsistent across harvests and between nutrient sources (Table 2). The significant interactions (Table 1) involving nutrients are the result of a combination of rank and magnitude changes. The tallest plants $(60.7 \mathrm{~cm})$ were found with irrigation + manure under shade at Harvest 3 and the shortest plants were found with inorganic fertilizer in full sun in Harvest 4 (Table 3).

Dry matter. Dry matter content was significantly higher in plants grown in full sun than in plants grown under shade at all harvests (Table 2). Irrigation significantly decreased dry matter content at all harvests except the last; the highest average decrease (21\%) was observed for Harvest 3. Significant interactions involving shade and irrigation (Table 1) were the result of magnitude effects.

Nutrient application significantly reduced dry matter content by small (less than $10 \%$ ) amounts in Harvests 2 and 3 and by up to $25 \%$ for the organic fertilizer treatment at Harvest 4 (Table 2). The significant irrigation $\times$ nutrient interaction at the second harvest (Table 1) can be explained by the fact that inorganic and organic fertilizer decreased percent dry matter compared with the control without irrigation but had no effect with irrigation (data not shown).

Higher percent dry matter in the first harvest of each year $(1,3)$ than in the second $(2,4)$ (Table 2) may be explained by the fact that at the second harvest of each year, there was less time for regrowth to mature and also because of moist soil conditions resulting from higher rainfall during these periods.

Dry matter yield. Shade had no significant effect on dry matter yield at Harvest 1 but increased yield by $64 \%$ at Harvest $2,63 \%$ at Harvest 3, and almost 11-fold at Harvest 4 (Table 2). Higher yield under shade may be explained by much higher survival at later harvests under shade than in full sun and also because plants under shade grew taller and were more vigorous. Better growth and yield under shade and irrigation is consistent with its natural habitat of moist soils and cool, shady conditions found in swampy woods (Awad et al., 2003). None of the two-way interactions were significant (Table 1).

Irrigation increased dry matter yield at all harvests, although the difference was nonsignificant at Harvest 2 (Table 2). Irrigation nearly quadrupled yield at Harvest 3 , which was preceded by a period of $38 \mathrm{~d}$ with inadequate rainfall. Irrigation may be more critical in full sun than under shade as a result of higher moisture stress in full sun than under shade.

Addition of inorganic or organic fertilizer significantly increased yield at Harvests 1 and 3 (Table 2). For the other two harvests, differences were less than $30 \mathrm{~kg} \cdot \mathrm{ha}^{-1}$ and main effects did not test significant. A significant irrigation $\times$ nutrient interaction for Harvest 2 (Table 1) was the result of inconsistent responses of inorganic and organic fertilizers between irrigated and non-irrigated conditions.

The significant irrigation $\times$ nutrient interaction at Harvest 3 (Table 1) is the result of 
a magnitude effect, in which the addition of nutrients under irrigation resulted in 2.5- and 3.4-fold yield increases for inorganic and organic fertilizer, respectively, under irrigation; without irrigation, inorganic and organic fertilizer increased yields by $26 \%$ and $41 \%$, respectively (data not shown). This highlights the importance of water in nutrient uptake by plants.

The highest dry matter yield for individual harvests $\left(1211 \mathrm{~kg} \cdot \mathrm{ha}^{-1}\right.$ and $1280 \mathrm{~kg} \cdot \mathrm{ha}^{-1}$ at Harvest 3 ) and for highest total dry matter yield for the four harvests (2720 and 2662 $\mathrm{kg} \cdot \mathrm{ha}^{-1}$ ) were obtained with the irrigation + fertilizer and irrigation + manure treatments, respectively, under shade (Table 3). The highest yield for an individual harvest in full sun, $1162 \mathrm{~kg} \cdot \mathrm{ha}^{-1}$ at Harvest 3, and highest total yield, $1995 \mathrm{~kg} \cdot \mathrm{ha}^{-1}$, were also obtained with the irrigation + manure treatment. The lowest total yields for the four harvests $\left(725 \mathrm{~kg} \cdot \mathrm{ha}^{-1}\right.$ and $\left.771 \mathrm{~kg} \cdot \mathrm{ha}^{-1}\right)$ were obtained in full sun with the fertilizer and control treatments, respectively.

\section{Conclusions}

American skullcap can be successfully cultivated in the Southeast. Shade and irrigation were the controlling factors in this experiment. The main constraints encountered were drought stress, which led to stand losses and reduced yields and powdery mildew.
Without irrigation, survival and response to added nutrients was low, resulting in lower yield. Shade substantially increased yield but was accompanied by higher incidence of powdery mildew. In full sun, the risk of stand depletion over time is greater. Highest yield can be expected with shade, irrigation, and added nutrients.

\section{Literature Cited}

Awad, R., J.T. Arnason, V.L. Trudeau, C. Bergeron, J.W. Budzinski, B.C. Foster, and Z. Merali 2003. Phytochemical and biological analysis of skullcap (Scutellaria lateriflora L.): A medicinal plant with anxiolytic properties. Phytomedicine 10:640-649.

Azaizeh, H., L. Predrag, I. Portnaya, O. Said, U. Cogan, and A. Bomzon. 2005. Fertilization induced changes in growth parameters and antioxidant activity of medicinal plants used in traditional Arab medicine. Evid. Based Complement. Alternat. Med. 2:549-556.

Bergeron, C., S. Gafner, E. Clausen, and J.D. Carrier. 2005. Comparison of the chemical composition of extracts from Scutellaria lateriflora using accelerated solvent extraction and supercritical fluid extraction versus standard hot water or supercritical fluid extraction versus standard hot water or $70 \%$ ethanol extraction. J. Agr. Food Chem. 53:3076-3080.

Brevoort, P. 1998. The booming U.S. botanical market: A new overview. HerbalGram 44:3346.

Foster, S. and J.A. Duke. 2000. Medicinal plants and herbs of Eastern and Central North America. $2^{\text {nd }}$ Ed. Houston Mifflin Co., New York, NY. p. 211.

Janke, R. and J. DeArmond. 2004. Farming a few acres of herbs: Skullcap. Kansas State University Research and Cooperative Extension Service: MF-2628, May 2004.

Joshee, N., T.S. Patrick, S.M. Rao, and A.K. Yadav. 2002. Skullcap: Potential medicinal crop. p. 580-586. In: Janick, J. and A. Whipkey (eds.). Trends in new crops and new uses. ASHS Press, Alexandria, VA.

Mannfried, P. 1993. Healing plants. Barron's Educational Series, Inc., Hauppauge, NY.

Sturdivant, L. and T. Blakley. 1999. Medicinal herbs in the garden, field and marketplace. San Juan Naturals, Bootstrap Press, Friday Harbor, WA. p. 116-117.

Upton, R. (ed.). 2009. Skullcap aerial parts Scutellaria lateriflora $\mathrm{L}$. Standards of analysis, quality control, and therapeutics. American Herbal Pharmacopoeia ${ }^{\circledR}$, Scotts Valley, CA.

USDA. 2011. Plants database. Natural Resources Conservation Service, U.S. Department of Agriculture. 26 Aug. 2011. <http://plants.usda. gov/java/profile?symbol=SCLA2 $>$.

Wills, R.B.H. and D.L. Stuart. 2004. Generation of high quality Australian skullcap products. A report for the Rural Industries Research and Development Corporation, RIRDC Publication No. 04/020, Australian Government. ISBN 0642587302, ISSN 1440-6845.

Zheljazkov, V.D., C.L. Cantrell, M.W. Ebelhar, C. Coker, and W.B. Evans. 2007. Quality assessment and yield of Baikal skullcap (Scutellaria baicalensis) grown at multiple locations. HortScience 42:1183-1187. 